\title{
Reproductive biology and pollination of Cabomba aquatica (Cabombaceae)
}

Biologia reprodutiva e polinização de Cabomba aquatica (Cabombaceae)

\author{
Jacilene Bezerra da Silva ${ }^{1}$ \& Ana Virgínia de Lima Leite $e^{1,2}$
}

\begin{abstract}
Reproductive biology and pollination of the fanwort, Cabomba aquatica Aubl., were studied in populations from dams located in Dois Irmãos State Park, Recife, Pernambuco state, northeastern Brazil. Flower anthesis in this species is diurnal and lasts two days. The flowers are bisexual and exhibit herkogamy and incomplete protogyny. Each flower produces an average of $2.1 \pm 94.8$ pollen grains, with a $\mathrm{P} / \mathrm{O}$ ratio of 1.055 and high pollen viability (99.7\%). This species is self-compatible, but requires biotic vectors to transfer pollen. We observed visits of bees (Apidae and Halictidae), wasps (Vespidae) and flies (Diptera) to the flowers. Bees and wasps were considered to be effective pollinators, both due to their behavior and their high frequency of visits to flowers, whereas flies were considered to be occasional pollinators. The floral mechanism (herkogamy and protogyny), together with low nectar production and pollinator behavior during visits, may contribute to increase pollen flow between individuals.

Key-words: Cabomba, dichogamy, entomophily, herkogamy, self-compatibility.

\section{Resumo}

A biologia reprodutiva e a polinização de Cabomba aquatica Aubl. foram estudadas em populações presentes em açudes localizados no interior do Parque Estadual de Dois Irmãos, Recife, PE. A antese das flores é diurna, com dois dias de duração. As flores são bissexuais e apresentam hercogamia e protoginia incompleta. Cada flor produz em média $2.111 \pm 94$ grãos de pólen, com uma razão P/O de 1,055 e elevada viabilidade polínica (99,7\%). A espécie é autocompatível, porém demonstrou a necessidade de vetores bióticos para a transferência do pólen. Foram observadas visitas de abelhas (Apidae e Halictidae), vespas (Vespidae) e moscas (Diptera). As abelhas e vespas foram consideradas como polinizadores efetivos, tanto pelo comportamento como pela alta freqüência nas visitas, enquanto que as moscas foram consideradas polinizadores ocasionais. O mecanismo floral (hercogamia e protoginia), associado com a baixa produção de néctar e o comportamento dos polinizadores durante as visitas podem contribuir para aumentar o fluxo polínico entre os indivíduos.

Palavras-chave: Auto-compatibilidade, Cabomba, dicogamia, entomofilia, hercogamia.
\end{abstract}

\section{Introduction}

Aquatic vascular plants are widely distributed in tropical and subtropical regions (Penha et al. 1999). They constitute a type of vegetation with a high primary production rate (Esteves 1998), having an important ecological role as a food source, a place of refuge for several vertebrate and invertebrate species (SánchezBotero et al. 2003; Albertoni et al. 2005), and they are also biomass producers and nutrient stockers (Granéli \& Solander 1988; Esteves 1998). About 79 families and 380 genera of angiosperms have aquatic species representatives (Cook 1988), the Nymphaeales order being exclusively aquatic.
Nymphaeales represents one of the three branches of ANITA clade, which consists of basal plants (Zimmer et al. 2000; Thien et al. 2009). This order traditionally includes two families: Nymphaeaceae and Cabombaceae (Brasenia Schreb., Cabomba Aubl.) (Taylor et al. 2008). In many representatives of this order, flowers are bisexual and protogynic, produce floral odor, show thermogenesis (Victoria Lindl. and Nymphaea L. - Nymphaeaceae), are pollinated mainly by beetles and flies and some taxa are self-compatible (see Thien et al. 2000, 2009). Nectar seems to be present only in Cabomba and Nuphar Sm. genera (Thien et al. 2009).

\footnotetext{
'Universidade Federal Rural de Pernambuco, Depto. Biologia, Botânica, R. Dom Manoel de Medeiros s/n, Dois Irmãos, 52171 - 900, Recife, PE, Brasil.

${ }^{2}$ Autor para correspondência: virginialeite@yahoo.com
} 
The Cabombaceae family has approximately six to nine species and is distributed throughout tropical and temperate regions of the American continents and West Indies, also occurring in Asia, Australia and Africa (Osborn \& Schneider 1988; Ørgaard 1991). This family inhabits lentic and lotic freshwater environments, and Cabomba aquatica Aubl. is the only representative native to the state of Pernambuco (Francisco \& Barreto 2007).

Studies related to pollination and reproduction in Cabombaceae are restricted to Cabomba caroliniana A. Gray (Taver \& Sanders 1977; Schneider \& Jeter 1982; Osborn et al. 1991) and Brasenia schreberi J.F. Gmel. species (Osborn \& Schneider 1988; Osborn et al. 1991). In these species, flowers are pollinated by Diptera and Hymenoptera (in Cabomba) and by the wind (Brasenia only) (see Schneider \& Jeter 1982; Osborn \& Schneider 1988; Thien et al. 2009). In Cabomba, nectar is produced at the base of the petals, which are ear-shaped (Schneider \& Jeter 1982; Vogel 1998; Francisco \& Barreto 2007). Recent studies (Thien et al. 2000, 2009) do not mention the type of reproductive system found in these two genera; however, Schneider \& Jeter (1982) report that there is no fruit formation by apomixis or spontaneous pollination in $C$. caroliniana and, based on experiments, they considered the species to be auto-compatible. The present study represents the first record on floral biology, reproductive system and pollination in Cabomba aquatica.

\section{Material and Methods}

\section{Study area}

The present study was carried out at Dois Irmãos State Park, an Atlantic Forest fragment, with an area of 388.64 ha, located near urban areas, northwest of the city of Recife, Pernambuco ( $\left.8^{\circ} 7^{\prime} 30^{\prime \prime} \mathrm{S} ; 34^{\circ} 52^{\prime} 30^{\prime \prime} \mathrm{W}\right)$. Climate in the region is classified as hot and humid, with humid weather between March and September and dry weather from August to February (Coutinho et al. 1998).

The park has two large water reservoirs on the premises, namely "do Meio" dam and "do Prata" dam. A third reservoir (Dois Irmãos) is situated in the area which comprises the zoo (inside the park). The "do Meio" and "do Prata" dams constitute the Prata Basin, which belongs to the Pernambuco Sanitation Company (COMPESA). Field analyses were carried out from March to November 2009, and additional information was gathered between
January and March 2011. The C. aquatica individuals studied were located near the banks of "do Meio" dam (with many populations of this species) and the reservoir located on the zoo premises, c. $150 \mathrm{~m}$ distant from one another.

\section{Floral biology}

Anthesis and floral longevity were determined by direct observation in the field of 15 flowers. As the flowers have a two-day duration (see results above), stigma receptivity was tested in first-day flowers $(n=10)$ and second-day flowers $(\mathrm{n}=10)$, previously bagged, using hydrogen peroxide $\left(\mathrm{H}_{2} \mathrm{O}_{2}\right)$. On the second day of anthesis, receptivity was verified after anther dehiscence. Osmophore (scent gland) areas were identified in 10 flowers, previously bagged and stained using the neutral red technique (Vogel 1990), and tests were carried out on the first and second days of anthesis.

In the laboratory, stamen lengths were measured using a digital caliper to an accuracy of $0.01 \mathrm{~mm}$. For this analysis, 40 flowers were randomly collected from different populations, 20 on the first day of anthesis and 20 on the second day of anthesis. The number of total pollen grains per anther was estimated using a microscope, where 10 buds in preanthesis were collected, and direct counting (on semipermanent slides) of all pollen grains was done for two anthers taken from these buds with the aid of a hand counter. For these same 10 flowers, the number of ovules was counted with a stereomicroscope. Then the pollen-ovule ratio $(\mathrm{P} / \mathrm{O})$ was calculated by dividing the total number of pollen grains by the number of ovules, in each bud, according to Cruden's method (1977). During the counting of pollen grains, pollen viability was tested with $2 \%$ acetic-carmine staining (Radford et al. 1974). In order to determine sugar concentration in the nectar, 30 buds in preanthesis were bagged and, during anthesis, liquid content inside each open flower was removed using a graduated microsyringe to $5 \mu$, and concentration was measured with a hand-held refractometer $(0$ $30 \%$, Atago ${ }^{\circledR}$ ).

\section{Reproductive System}

For reproductive-system analysis, controlled hand-pollination tests were carried out (Radford et al. 1974), such as: 1) spontaneous self-pollination, in which 100 buds in pre-anthesis were wrapped in "voile" fabric $(0.05 \mathrm{~mm}$ mesh) and observed as to fruit formation; 2) hand self-pollination, in which 25 buds in pre-anthesis were bagged, and self- 
pollination was carried out on the second day of floral anthesis using pollen from the same flower, and 3) cross-pollination, performed on 50 previously bagged flowers. Crossing was done in 25 flowers on the first day and in 25 flowers on the second day of anthesis, previously emasculated. Pollen donors and pollen recipients were c. $150 \mathrm{~m}$ from each other. In order to evaluate the efficiency of natural pollination (control), 100 flowers were marked and kept in exhibition for visitors. In all of the three hand-operated treatments, $5 \mathrm{~cm}$ styrofoam cubes were placed in the "voile" bags to allow bag fluctuation and to provide enough room for the buds to open. Each reproductive treatment was monitored regarding fruit formation.

The Index of Self-Incompatibility (ISI), which is the ratio between the proportion of fruits produced by hand self-pollination divided by the number of fruits produced by cross-pollination, was measured according to Bullock (1985). Fruit formation by natural pollination (control) was compared to fruit formation by hand selfpollination and cross-pollination. Fruit production from the hand self-pollination treatment was compared to the cross-pollination treatment. For these analyses, Chi-square $\left(\chi^{2}\right)$ test was used, with the aid of BioEstat 3.0 software (Ayres et al. 2003).

\section{Floral visitors}

Time of day, total number of visited flowers and behavior of floral visitors plus floral resource used, were obtained by direct observation in the field at different times during the period of anthesis (between 8:30 am and 01:30 pm), from March to July 2009, totaling 30 observation hours.

For frequency analysis, an area of approximately $1 \mathrm{~m}^{2}$ containing $C$. aquatica plants was selected. In this area, visited flowers were counted and visit times were recorded. During the frequency analysis, floral visitors' behavior was observed directly. According to contact efficiency of flower reproductive parts , the pollinators were classified as: 1) effective, when they frequently had contact with flower reproductive structures, and 2) occasional, when contact with reproductive structures did not always happen.

Visits were documented photographically. For identification of floral visitors, insects were collected in killing jars and then they were properly packed, mounted and identified (when possible).

\section{Results}

\section{Morphology and floral biology}

Cabomba aquatica is an aquatic weed, with stem and leaves submerged. Flowers are bisexual, isolated, with six stamens, longitudinally dehiscent anthers, apocarpous gynoecium, one ovule per carpel; yellow, zygomorphic corolla. The floral buds develop under water and only emerge on floweropening day. In each individual, one flower opens per day. Flowering in this species usually extends over the entire year.

The species is protogynic and anthesis takes two days, starting at about 8:30 am, with stigmas already receptive. On the first day of anthesis (Fig. 1a), stamens are short $(2.63 \mathrm{~mm} \pm 0.1)$ with closed anthers, located well bellow the gynoecium. Between 12:00 pm and 01:30 pm, closing and submersion of the plants occur. On the second day, between 8:30 am and 9:00 am, flowers emerge, filaments grow, elevating the anthers above the gynoecium, reaching $6.2 \pm 0.5 \mathrm{~mm}$ height, and stigmas remain receptive (Fig. 1b). Anther opening takes place at about 10:00 am on the second day of anthesis. At the end of the second day, the flower closes and fruit ripening occurs totally under water. On a same day, in a same $C$. aquatica population, flowers at different stages of anthesis were recorded. Flowers did not have a noticeable odor, and areas with osmophore concentrations were not observed with neutral red. Each flower produces an average of 2,111 \pm 94.8 grains of pollen, the pollen/ovule ratio $(\mathrm{P} / \mathrm{O})$ being c. 1,055, since flowers had two ovules. A high pollen viability ratio was observed $(99.7 \%)$. Regarding the presence of nectar, it was observed that, in 30 flowers collected, sugar concentration was $3 \%$. For the bagged flowers, small droplets running down the inside of the flower were observed at the atria of the petals.

\section{Reproductive system}

During spontaneous self-pollination treatment, there was no fruit formation. During hand self-pollination treatment, nine fruits were obtained from 25 flowers handled. In crosspollination, 19 fruits were obtained from flowers on the first day of anthesis, and 17 fruits were obtained from flowers on the second day of anthesis. The calculated ISI for this species was 0.25 . Under natural conditions (control), formation of 94 fruits from 100 marked flowers was observed, with a significant difference when compared to 

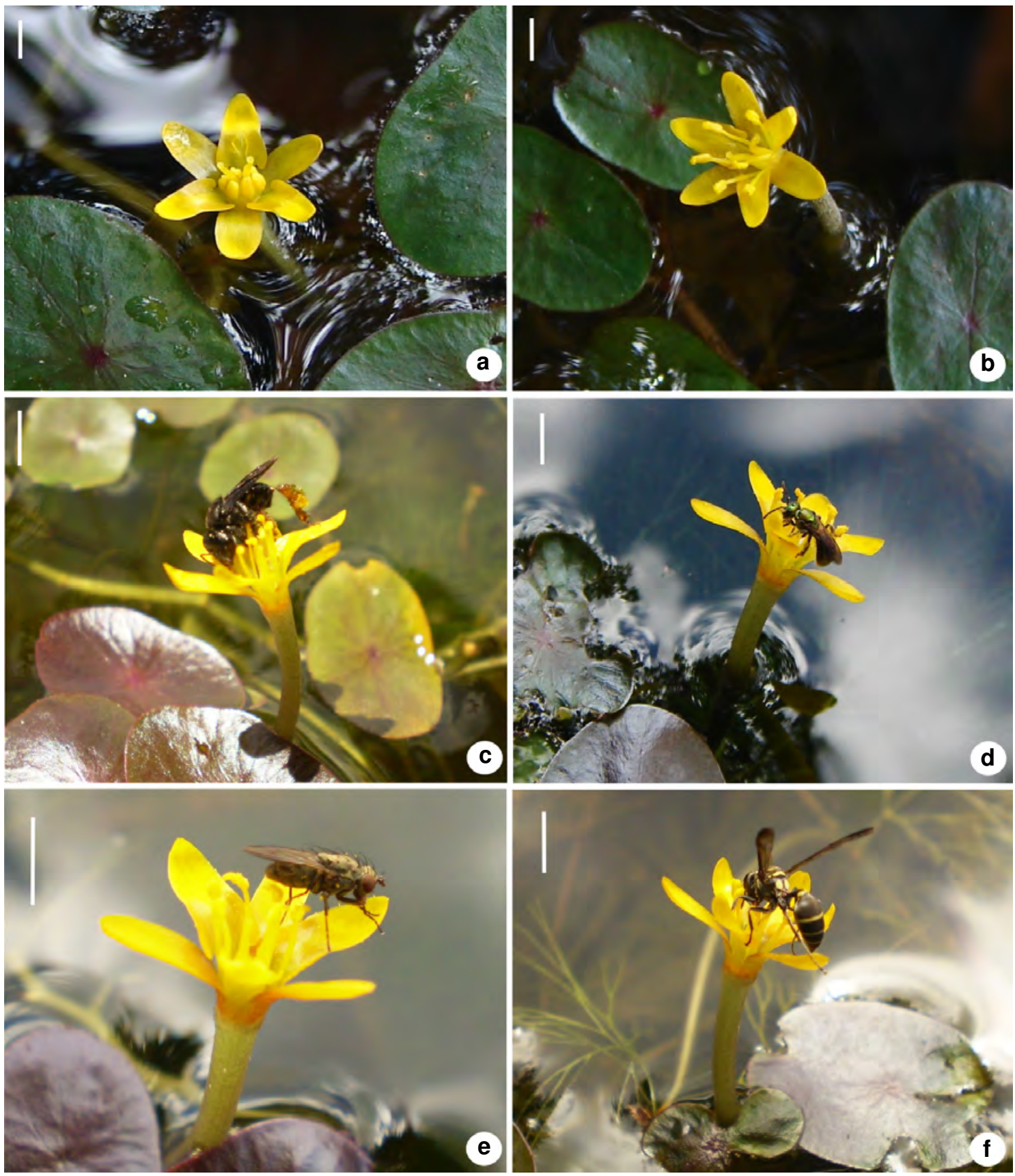

Figure 1 - Cabomba aquatica Aubl. - a. flower on the first day of anthesis; b. flower on the second day of anthesis. c-f. flower visitors - c. Trigona spinipes Fabricius, 1793 collecting pollen on a flower on the second day of anthesis; d. Augochlora sp. collecting nectar; e. Diptera visiting the flower; f. Polybia sp. collecting nectar.

hand self-pollination $\left(\chi^{2}=5.645 ; \mathrm{g} .1 .=1 ; \mathrm{p}=0.0175\right)$, but not to cross-pollination $\left(\chi^{2}=1.041 ;\right.$ g.1. $=1 ; \mathrm{p}=$ $0.3075)$. Fruit production by hand self-pollination was not significantly different from crosspollination $\left(\chi^{2}=2.462 ; \mathrm{g} .1 .=1 ; \mathrm{p}=0.1166\right)$.

\section{Floral visitors}

Among C. aquatica floral visitors are bees that visit many species of plants for pollination, such as Apidae (Apis mellifera L. and Trigona spinipes Fabricius, 1793) and Halictidae 
Table 1 - Floral visitors, behavior during the visit, floral phase and resource collected by insects visitors of Cabomba aquatica Aubl. (Cabombaceae) flowers.

\begin{tabular}{|c|c|c|c|c|c|c|}
\hline \multirow[t]{2}{*}{ Floral visitors } & \multicolumn{2}{|c|}{ Pollinator } & \multicolumn{2}{|c|}{ Floral phase } & \multicolumn{2}{|c|}{ Resource } \\
\hline & Effective & Occasional & Female & Hermaphrodite & Nectar & Pollen \\
\hline Apis mellifera $\mathrm{L}$. & $\mathrm{X}$ & & & $\mathrm{X}$ & & $\mathrm{X}$ \\
\hline Trigona spinipes Fabricius, 1793 & $\mathrm{X}$ & & & $\mathrm{X}$ & & $\mathrm{X}$ \\
\hline Augochlora cf thalia & $\mathrm{X}$ & & $\mathrm{X}$ & $\mathrm{X}$ & $\mathrm{X}$ & $\mathrm{X}$ \\
\hline Augochlora sp. & $\mathrm{X}$ & & $\mathrm{X}$ & $\mathrm{X}$ & $\mathrm{X}$ & $\mathrm{X}$ \\
\hline Polybia sp. & $\mathrm{X}$ & & $\mathrm{X}$ & $\mathrm{X}$ & $\mathrm{X}$ & \\
\hline Diptera & & $\mathrm{X}$ & $\mathrm{X}$ & $\mathrm{X}$ & $\mathrm{X}$ & \\
\hline
\end{tabular}

(Augochlora cf. thalia Smith, 1879 and Augochlora sp.) representatives (Fig. 1c-d), a fly species (Fig. 1e) and a wasp species (Polybia sp.) (Fig. 1f). As of the first flower-opening hours, all flower visitors are active, some of them remaining active until flower closing. Nectar from inside the flower was the main resource sought by floral visitors (Tab. 1). Halictidae bees collected nectar as well as pollen, but Apidae bees collected pollen only.

Apis mellifera and T. spinipes individuals approached on a recognition flight, landed only on flowers on the second day of anthesis, manipulated the anthers with their front pair of legs, collecting pollen grains and transferring them to their rear legs (Fig. 1c).Apis mellifera was one of the most frequent flower visitors, with visiting peak between 10:00 am and 12:00 pm (Fig. 2). Due to its size, its abdomen remained outside the corolla during the visit, while its thorax came in contact with the anthers and was covered by pollen. At this moment, insect contact with the stigmas was observed. Trigona spinipes acted more intensely between 10:00 am and 11:00 am, with frequency reduced on cloudy days. Since they come in contact with the reproductive structures, both species were considered to be effective pollinators (Tab. 1).

Augochlora cf. thalia and Augochlora sp. approached the flowers without a recognition flight. In flowers on the first day of anthesis, they sought nectar as a floral resource, walking through the entire flower, introducing their heads inside the flower (Fig. 1d). In flowers on the second day of anthesis, they were also observed collecting pollen, and depositing both nectar and pollen on the rear legs. Pollen grains adhered to the abdomen and rear legs of these species were frequently observed being deposited on the stigma region, which characterizes the behavior of an effective pollinator (Tab. 1). Augochlora cf. thalia was more frequent

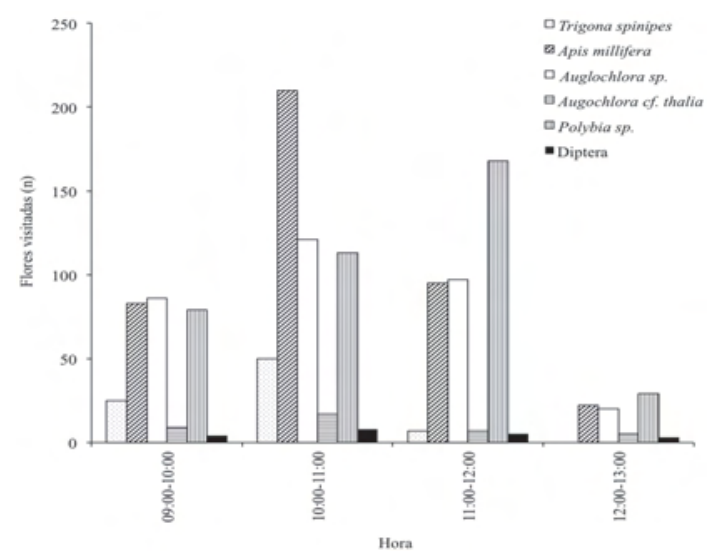

Figure 2 - Frequency of visitors to flowers of Cabomba aquatica Aubl. at Parque Estadual de Dois Irmãos.

between 10:00 am and 11:00 am, reducing the number of visits after 12:00 pm, while Augochlora sp. showed one of the longest visitation periods for $C$. aquatica flowers, present from the first hours of anthesis to the closing of the flowers (Fig. 2). When approaching the flowers, it initially landed on the petals and sepals. Its small size allowed the insect to walk through all of the floral structures. When visiting flowers during the period they were closing, it completely introduced its body inside the flower, coming in contact with the reproductive structures of the flower.

Only one representative of the Diptera order (Fig. 1e) was observed on flowers in anthesis, remaining still most of the time and visiting only a small number of flowers (during both phases) (Fig. 2), which only happened when it was disturbed by an effective pollinator. Due to its behavior, this species was considered to be an occasional pollinator.

A representative of Vespidae (Polybia sp.) family (Fig. 1f) was also observed as a C. aquatica floral visitor. From field observations, it was verified 
that the wasp landed on the flowers to collect nectar, visiting either flowers on the first and second days of anthesis. The wasp frequently used the floating leaf as a landing platform and climbed the pedicel at the corolla searching for food. When walking through the flower, the ventral region of its thorax and abdomen came in contact with the anthers, and when its head was thrust between the reproductive structures, it became loaded with pollen. As it frequently came in contact with the reproductive structures, it was considered to be an effective pollinator.

\section{Discussion}

Cabombaceae shares some of the floral characteristics presented by basal angiosperms of the clade ANITA (Thien et al. 2009), such as small, bisexual, protogynic flowers, pollination by insects and apocarpous gynoecium. However, this family, along with Nymphaeaceae representatives, differs by having aquatic species (see Endress 2001; Thien et al. 2000, 2009).

Cabomba aquatica has floral morphology similar to other representatives of the genus (Tarver \& Sanders 1977; Schneider \& Jeter 1982). The difference in spatial arrangement between the reproductive structures, observed in $C$. aquatica flowers, was also recorded for $C$. caroliniana (Schneider \& Jeter 1982), as well as for Brasenia schreberi (Osborn \& Schneider 1988), which suggests that herkogamy is a common characteristic to the family. In $C$. aquatica, herkogamy is homomorphic, since flowers have the same shape. As the pollinator comes in contact with pollen and stigma many times during visits and it does not happen in any particular sequence, this type of homomorphic herkogamy can also be considered less specific (sensu Webb \& Lloyd 1986).

Protogyny is also a characteristic of the family, and recorded for other species belonging to the clade ANITA, representatives of Nymphaeaceae, Austrobaileyaceae and Illiciaceae families (see Thien et al. 2009). In C. aquatica, flowers had incomplete protogyny (Lloyd \& Webb 1986), since the stigma remains receptive on the second day of floral anthesis. These results contrasted with those of Schneider \& Jeter (1982) for C. caroliniana flowers, which present absolute protogyny, and overlap between stigma receptivity and pollen liberation from the anthers does not occur at any moment during the two days of anthesis.

The presence of protogyny in $C$. aquatica prevents the transference of grains of pollen from the flower itself to the stigma during the first day of the flower, therefore supporting crosspollination. Although herkogamy is a floral mechanism which, in some cases, prevents selfpollination (see Endress 1994), this type of pollination may happen in the studied species due to pollinator participation and its behavior on the flowers on the second day of anthesis. Even though there is a significant difference in fruit production by hand self-pollination and crosspollination, the high percentage of pollen viability and the value presented for the $\mathrm{P} / \mathrm{O}$ ratio $(1,055)$ place this species among xenogamic ones (sensu Cruden 1977); moreover, the calculated ISI was 0.25 , which is very close to that of selfincompatible species, considered by Bullock (1985) for species of a deciduous rain forest (ISI < $0.24)$. The low nectar production per flower also induces the pollinator to visit diverse flowers, raising the probability of cross pollination. On the other hand, self-pollination can also be an advantage for $C$. aquatica, which colonizes aquatic environments that may, in some cases, be distant from other populations of the same species. Under these conditions, individuals may suffer from scarcity of pollinators or, when present, pollinators may not fly routes distant enough to promote cross-pollination between genetically different individuals (see Schneider \& Jeter 1982).

For the genus Cabomba, only $C$. caroliniana has been studied as to pollination. In this species, flowers do not emit noticeable odor, are self-compatible, offer pollen and nectar as a resource and nectar production is much reduced (Schneider \& Jeter 1982). Taruer \& Sanders (1977) report that there is no fruit production in this species when flowers open, still submerged, and that pollination is essentially cross-pollination. In C. caroliniana, fruit production occurs only in flowers pollinated on the first day of anthesis (Schneider \& Jeter 1982), different from what was observed for $C$. aquatica in the present study, where fruit production by cross-pollination occurred in flowers crossed on the first and on the second days of anthesis. Pollen viability in C. caroliniana is between $45-95 \%$, producing about $560 \pm 123$ grains of pollen per flower, with low $\mathrm{P} / \mathrm{O}$ ratio $(62 \pm 14)$ (Osborn et al. 1991). In contrast to what was reported for Cabomba, in Brasenia schreberi, another Cabombaceae species and the only representative of the genus, studies show differences in the quantity of grains 
of pollen per flower $(221 \pm 15)$ and in the $\mathrm{P} / \mathrm{O}$ ratio $(9.24 \pm 625)$, and also wind pollination (Osborn \& Schneider 1988; Osborn et al. 1991).

For C. aquatica, bees were considered to be the main pollinators. A. mellifera and $T$. spinipes visits only to flowers on the second day of anthesis made self-pollination possible, since pollen may fall on the stigma during pollen collection. On the other hand, the high frequency of visits by A. mellifera also promotes self-pollination. Under this condition, the flower can receive a mixture of pollen from itself and from flowers of different individuals. In contrast, Augochlora spp. and Polybia sp. visited flowers frequently and in both phases, contributing more effectively to cross-pollination among individuals. The fly species observed also visited flowers on the first and second days of anthesis, contributing to pollen flow, but less effectively, since there was a low frequency of visits. In $C$. caroliniana, pollination was mediated mainly by flies (Notiphila cressoni Mathis, 1979 and Hydrellia bilobifera Cresson, 1936), along with the participation of bees (Halictidae) and wasps (Braconidae) (Schneider \& Jeter 1982). Tarver \& Sanders (1977) mentioned, for this same species, pollination by A. mellifera and Halictus sp., as well as by two Odonata species (Anax sp. Aeshnidae and Enallagma sp. Coenagrionidae). However, in the latter case, pollination must occur accidentally, since these species do not eat pollen or nectar.

Pollination done mainly by bees in $C$. aquatica differs from what was reported by Thien et al. (2000), where beetles and flies are the primary pollinators of basal angiosperms, while bees, although important, are secondary vectors. Yet, more recently, Thien et al. (2009) emphasize that pollination by beetles in basal angiosperms must be re-examined, since new information for species of the ANITA clade indicate pollination by wind, flies and bees.

The characteristics of the floral biology and the reproductive system of $C$. aquatica are the same, in part, as those that have already been described in literature for this genus, presenting diurnal flowers, which last two days, having spatial separation (herkogamy) between reproductive structures and self-compatible flowers. However, it differs as to the type of protogyny (incomplete), and above all as to the pollinators (mainly bees and wasps). Controlled pollination tests and analysis of pollinator frequency show that reproduction in this species depends on pollen transfer done by pollinators.

\section{Acknowledgments}

The authors thank biologists Leonardo Barbosa da Silva and Pedro Bismara (UFRPE), for assistance provided during field observations, Dr. André Santos (UFPE/CAV), for the initial reading of the manuscript, and the direction of Dois Irmãos State Park, for authorizing research on the Park premises.

\section{References}

Albertoni,E.F.; Palma-Silva, C. \& Veiga, C.C. 2005. Estrutura da comunidade de macroinvertebrados associada às macrófitas aquáticas Nymphoides indica e Azolla filliculoides em dois lagos subtropicais (Rio Grande, RS, Brasil). Acta Biologica Leopondensia 27: 137-145.

Ayres, M.; Ayres Júnior, M.; Ayres, D.L. \& Santos, A.S. 2003. BioEstat 3.0. Aplicações estatísticas nas áreas das ciências biológicas e médicas. Sociedade Civil Mamirauá, MCT-CNPq/Conservation International, Belém. 291p.

Bullock, S.H. 1985. Breeding systems in the flora of a tropical deciduous forest in Mexico. Biotropica 17: 287-301.

Cook, C.D.K. 1988. Wind pollination in aquatic angiosperms. Annals of the Missouri Botanical Garden 75: 768-777.

Coutinho, R.Q.; Lima, M.F.; Souza-Neto, J.S. \& Silva, E.P. 1998. Características climáticas, geológicas, geomorfológicas e geotécnicas da Reserva Ecológica de Dois Irmãos. In: Machado, I.C.; Lopes, A.V. \& Pôrto, K.C. (eds.). Reserva Ecológica de Dois Irmãos: estudos em um remanescente de mata atlântica em uma área urbana (Recife, Pernambuco, Brasil). Sectma, Editora Universitária, UFPE, Recife. Pp. 21-49.

Cruden, R.W. 1977. Pollen-ovule ratios: a conservative indicator of breeding systems in flowering plants. Evolution 31: 32-46.

Endress, P.K 1994. Diversity and evolutionary biology of tropical flowers. Cambridge University Press, Cambridge. 511p.

Endress, P.K 2001. The flowers in extant basal angiosperms and inferences on ancestral flowers. International Journal of Plant Science 162: 1111-1140.

Esteves, F.A. 1998. Fundamentos de limnologia. Ed. Interciência/FINEP, Rio de Janeiro. 602p.

Francisco, L.V. \& Barreto, R.C. 2007. Cabomba Aubl., Caracterização morfoecológica e delimitação entre as espécies ocorrentes no Brasil. Revista Brasileira de Biociências 5: 1077-1079.

Granéli, W. \& Solander, D. 1988. Influence of aquatic macrophytes on phosphorus cycling in lakes. Hydrobiologia 170: 245-266.

Lloyd, D.G. \& Webb, C.J. 1986. The avoidance of interference between the presentation of pollen and stigmas in angiosperms. I. Dichogamy. New Zealand Journal of Botany 24: 135-162. 
Ørgaad, M. 1991. The genus Cabomba (Cabombaceae) - taxonomic study. Nordic Journal of Botany 11: 179-203.

Osborn J.M. \& Schneider E.L. 1988. Morphopological studies of Nymphaeaceae sensu lato, XVI, The floral biology of Brasenia scharaberi. Annals of the Missouri Botanical Garden 75: 78-794.

Osborn, J.M; Taylor, T.N. \& Schneider, E.L. 1991. Pollen morphology and ultrastructure of the Cabombaceae: correlations with pollination biology. American Journal of Botany 78: 1367-1378.

Penha, J.M.F.; Silva, C.J. \& Bianchini J.I. 1999. Productivity of the aquatic macrophyte Pontederia lanceolata Nutt. (Pontederiacea) on floodplains of the Pantanal Mato-Grossense, Brazil. Wetland Ecology and Management 7: 155-163.

Radford, A.E.; Dickinson, W.C.; Massey, J.R. \& Bell, C.R. 1974. Vascular plant systematics. Harper \& Row Publishers, New York. 891p.

Sánchez-Botero, J.I.; Farias, M.L.; Piedade, M.T. \& Garcez, D.S. 2003. Ictiofauna associada às macrófitas aquáticas Eichhornia azurea (SW.) Kunth. e Eichhornia crassipes (Mart.) Solms no lago Camaleão, Amazônia Central, Brasil. Acta Scientiarum 25: 369-375.

Schneider, E.L. \& Jeter J.M. 1982. Morphological studies of the Nymphaeaceae: 12. The floral biology of Cabomba caroliniana. American Journal of Botany 69: 1410-1419.
Tauer D.P \& Sanders, D.R. 1977. Selected life cycle features of fanwort. Journal Aquatic Plant Management 15: 18-22.

Taylor, M.L.; Gutman, B.L.; Melrose, N.A.; Ingraham, A.M.; Scwartz, J.A. \& Osborn J.M. 2008. Pollen and anther ontogeny in Cabomba caroliniana (Cabombaceae, Nymphaeales) American Journal of Botany 95: 399-413.

Thien, L.B.; Azuma, H. \& Kawano, S. 2000. New perspectives on the pollination biology of basal angiosperms. International Journal of Plant Sciences 161: S225-S235.

Thien, L.B.; Bernhardt, P.; Devall, M.S.; Chen, Z-D.; Luo, Y-B.; Fan, J-H.; Yuan, L-C.; \& Williams, J.H.W. 2009. Pollination biology of basal angiosperms (ANITA grade). American Journal of Botany 96: 166-182.

Vogel, S. 1990. The role of scent glands in pollination. Smithsonian Institution Libraries, Washington. 202 p.

Vogel, S. 1998. Remarkable nectarines: structure, ecology, organophyletic perspectives II. Nectarioles, Flora 193: 1-29.

Webb, C.J. \& Lloyd, D.G. 1986. The avoidance of interference between the presentation of pollen and stigmas in angiosperms II. Herkogamy. New Zealand Journal of Botany 24: 163-178.

Zimmer E.A.; Qiu, Y-L.; Endress, P.K. \& Friis, E.M. 2000. Current perspectives on basal angiosperms: Introduction. International Journal of Plant Sciences 161: S1-S2. 